Jurnal Kesmas Asclepius

Volume 1, Nomor 1, Juni 2019

e-ISSN : 2684-8287

p-ISSN : 2656-8926

DOI: https://doi.org/10.31539/jka.v1i1.526

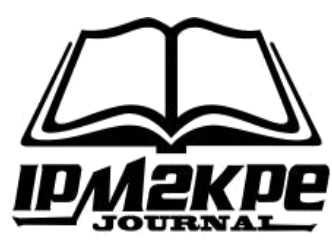

\title{
PERAWATAN INFEKSI SALURAN PERNAFASAN AKUT (ISPA) PADA BALITA
}

\author{
Padila $^{1}$, Henni Febriawati ${ }^{2}$, Juli Andri ${ }^{3}$, Rujung Ali Dori ${ }^{4}$ \\ Universitas Muhammadiyah Bengkulu ${ }^{1,2,3,4}$ \\ padila_ahmad@yahoo.co.id ${ }^{1}$
}

\begin{abstract}
ABSTRAK
Penelitian ini bertujuan untuk mengetahui hubungan pengetahuan dan sikap ibu dengan perawatan Infeksi Saluran Pernapasan Akut (ISPA) pada balita di wilayah kerja puskesmas Kembang Seri kecamatan Talang Empat kabupaten Bengkulu Tengah 2018. Jenis penelitian ini adalah survey analitik dengan pendekatan cross sectional. Hasil penelitian analisis univariat didapatkan dari 51 responden sebagian besar responden pengetahuan kurang sebanyak 21 orang $(41,2 \%)$. Sedangkan sebagian besar responden sikap yang kurang baik sebanyak 27 orang $(52,9 \%)$. Sedangkan Hasil analisis bivariat hubungan pengetahuan dan sikap ibu dengan perawatan ISPA pada balita dengan uji

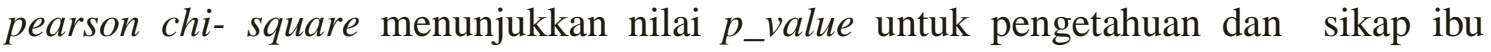
dengan perawatan ISPA $0,000 \leq \alpha 0,005$, artinya ada hubungan signifikan antara pengetahuan dan sikap ibu dengan perawatan ISPA pada balita di wilayah kerja puskesmas tersebut. Simpulan, peran serta keaktifan orang tua utamanya ibu, dalam mengikuti kegiatan promkes di puskesmas harus terjadwal.
\end{abstract}

Kata Kunci : Pengetahuan, Perawatan ISPA, Sikap

\begin{abstract}
This study aims to determine the relationship between knowledge and attitudes of mothers with the treatment of Acute Respiratory Infection (ISPA) in children under five in the work area of the Kembang Seri Public Health Center, Talang Empat District, Central Bengkulu District 2018. This type of research is an analytical survey with a cross sectional approach. The results of the univariate analysis research were obtained from 51 respondents, most of the respondents had low knowledge of 21 people (41.2\%). While most of the respondents had a bad attitude as many as 27 people (52.9\%). Meanwhile, the results of the bivariate analysis of the relationship between knowledge and attitudes of mothers with ARI care in toddlers with the Pearson Chi-square test showed that the p_value for knowledge and attitudes of mothers with ARI care was $0.000 \leq \alpha 0.005$, meaning that there was a significant relationship between knowledge and attitudes of mothers with ARI care in toddlers. in the working area of the puskesmas. Conclusion, the participation of parents, especially mothers, in participating in health promotion activities at the health center must be scheduled.
\end{abstract}

Keywords: Knowledge, ARI Treatment, Attitude 


\section{PENDAHULUAN}

WHO tahun 2016 menyatakan angka kejadian infeksi saluran pernafasan akut (ISPA) pada balita di tingkat dunia antara $15-20 \%$, insidensi ISPA di negara berkembang 0,29\% jiwa dan kawasan industri 0,05\% jiwa sedangkan angka kejadian ISPA di negara Indonesia 151 juta jiwa pertahun. Infeksi pada saluran napas adalah suatu penyakit yang umum terjadi pada masyarakat, dan menjadi salah satu penyebab kematian tertinggi pada anak di bawah usia 5 tahun (22,30\%). ISPA menempati urutan 10 besar penyakit di rumah sakit dan menempati urutan 9 dari 10 besar penyakit rawat inap di rumah sakit serta masuk 4 dari 10 Besar penyakit diwilayah puskesmas (Kemenkes RI, 2017).

ISPA merupakan infeksi akut yang menyerang saluran pernapasan bagian atas dan saluran pernapasan bagian bawah. virus, jamur dan bakteri merupakan penyebab dari infeksi ini. Secara garis besar, ISPA dibedakan menjadi common cold dimana pemicunya adalah virus rhinovirus, respiratory syncytial virus, adenovirus, dan influenza yang dipicu oleh virus influenza dengan berbagai tipe. Penyakit ini biasanya akan muncul pada saat musim pancaroba yang diakibatkan oleh sirkulasi virus di udara yang meningkat. Selain itu, perubahan udara dari panas ke dingin akan menyebabkan daya tahan tubuh anak menjadi lemah. Sehingga, anak menjadi lebih mudah terserang oleh penyakit ini (Sucipto, 2011).

ISPA dapat menyerang anak apabila ketahanan tubuh (immunologi) menurun. Biasanya menyerang anak di bawah lima tahun dan kelompok yang memiliki sistem kekebalan tubuh yang masih rentan terhadap berbagai penyakit (Prabowo, 2012). Penyakit ini di awali dengan suhu badan panas sekitar $38^{0} \mathrm{C}$ disertai salah satu atau lebih gejala : tenggorokan sakit atau nyeri menelan, keluar cairan melalui hidung, disertai batuk kering atau berdahak. Adapun komplikasi dari ISPA adalah otitis media, sinusitis, faringitis, pneumonia dan meninggal dunia karena sesak nafas (Padila, 2012).

Hal ini juga dipertegas oleh WHO (2008) gejala ISPA bisa bermacam-macam, mulai dari terjadinya demam, nyeri [ada tenggorokan, flu dan hidung tersumbat, batuk kering dan gatal, batuk berdahak, dan penyakit ini juga bisa menimbulkan komplikasi seperti radang paru dengan tanda-tanda terjadinya sesak napas. Pada bayi, bisa pula timbul bronkhiolitis (radang di saluran pernapasan halus di paru-paru) dengan gejala sesak dan napas berbunyi ngik-ngik. Selain itu, bisa pula terjadi laryngitis (peradangan pada daerah laring atau dekat pita suara) yang menimbulkan croup dengan gejala sesak saat menarik napas dan batuk menggonggong (barking cough).

Provinsi Bengkulu masih berada pada urutan ke-10 besar penyakit terbanyak tahun 2012, dengan angka insidensi 105.000 kasus, tahun 2013 terdapat 148.038 kasus dan tahun 2014 sebanyak 139.358 kasus. Lima kabupaten dengan ISPA tertinggi berdasarkan diagnosa gejala (DG) adalah Kaur (32,5\%), Bengkulu selatan (27,5\%), Kepahiang (26,6\%), Lebong (25\%) dan Bengkulu tengah (24,3\%) (Riskesdas, 2018).

Data bulanan program penanggulangan penyakit (P2) ISPA di kabupaten Bengkulu tengah tahun 2015 menyebutkan bahwa penderita ISPA pada balita mencapai 5.057 jiwa. Jumlah ini terhitung besar, mengingat jumlah balita diseluruh kabupaten ini tercatat berjumlah 11.548 jiwa. Berarti, hampir 5 dari 10 balita yang di kabupaten ini terinfeksi ISPA. Sementara itu, penderita ISPA biasa bila dirincikan sesuai umur, maka balita berumur 4-5 tahun tercatat sebagai penderita terbanyak dengan jumlah $61 \%$ dari seluruh penderita atau 3.084 jiwa pada tahun 2013 (Dinkes Benteng, 2017). 
Upaya yang telah dilakukan oleh pemerintah terhadap penyakit ISPA yaitu : Penemuan kasus pneumonia dilakukan secara aktif dan pasif, peningkatan mutu pelayanan melalui ketersediaan tenaga terlatih dan logistik, peningkatan peran serta masyarakat dalam rangka deteksi dini pneumonia balita dan pencarian pengobatan ke fasilitas pelayanan kesehatan, dan pelaksanaan autopsi verbal balita di masyarakat (Kemenkes RI, 2017).

Upaya yang tidak kalah penting adalah peran dari keluarga. Karena keluarga merupakan unit paling dekat dengan pasien, dan merupakan perawat utama bagi pasien. Keluarga memiliki peran dalam menentukan bagaimana perawatan yang diperlukan pasien saat berada di rumah. Walaupun peawatan di rumah sakit berhasil, tapi jika perawatan di rumah tidak diteruskan maka keberhasilan perawat di rumah sakit akan sia-sia sehingga akan mengakibatkan pasien akan mengalami kekambuhan. Peran serta keluarga mulai dari awal perawatan akan meningkatkan kemampuan keluarga merawat pasien sehingga memungkinkan pasien tidak kambuh atau dapat dicegah (Padila, 2013).

Keluarga merupakan bagian dari tim pengobatan dan perawatan. Para anggota keluarga menunggui secara bergantian, bahkan sering menjaga bersama-sama. Sementara perawat di rumah sakit yang seharusnya merawat orang sakit juga harus melakukan tugas-tugas yang lain di bangsal perawatan. Maka, peran keluarga penting untuk memantau kebutuhan pasien dari laporan perawat atau jika perlu malakukan komunikasi langsung. Peranan tersebut lebih dominan dari seorang ibu. Beberapa peranan ibu dalam melakukan upaya perawatan ISPA pada anakanya yaitu ibu harus mengetahui tentang ISPA mulai dari pengertian, penyebab, tanda dan gejala, proses perjalanan penyakit, komplikasi dan cara mengobati dan merawat anak semasa sakitnya tersebut agar bisa melakukan perawatan sedini mungkin dan sudah tahu bagaimana cara pencegahan ISPA tersebut (Choirunisa, 2015).

Data Puskesmas Kembang Seri Bengkulu Tengah, pada bulan Januari - Maret 2017 tercatat 358 kasus ISPA pada balita, dan berdasarkan survey awal yang dilakukan dari 10 orang ibu yang memiliki balita yang datang berobat ke Puskesmas Kembang Seri Bengkulu Tengah, 7 orang ibu diantaranya masih kurang pengetahuannya terhadap perawatan ISPA yang diderita balita, masih menganggap bahwa ISPA adalah penyakit yang biasa saja dibuktikan dengan anak sudah tiga hari batuk, flu, panas, ada juga yang sudah sesak nafas baru dibawa ke puskesmas, dan 3 orang ibu lainnya cukup mengetahui perawatan yang baik pada balita yang terserang ISPA. Wawancara yang dihasilkan dari perawat yaitu kegiatan promkes sering dilakukan pertiga bulan, akan tetapi masih sedikitnya kesadaran orangtua untuk mengikuti kegiatan tersebut. Adapun tujuan dari penelitian ini yaitu, untuk mendeskripsikan hubungan pengetahuan dan sikap Ibu dengan perawatan Infeksi Saluran Pernapasan Akut (ISPA) Pada Balita di Wilayah Kerja Puskesmas Kembang Seri Kecamatan Talang Empat Kabupaten Bengkulu Tengah.

\section{METODE PENELITIAN}

Jenis penelitian ini adalah penelitian survey analitik yaitu survey atau penelitian yang mencoba menggali bagaimana dan mengapa fenomena kesehatan itu terjadi. Dalam penelitian survei analitik ini, penelitian tidak dilakukan terhadap seluruh objek yang diteliti (populasi), tetapi hanya mengambil sebagian dari populasi tersebut (sampel). 
Penelitian ini menggunakan pendekatan cross sectional. Analisis data yang digunakan dalam penelitian ini adalah analisis univariat dan bivariat, dengan melakukan pengukuran variabel independent (bebas) yaitu tingkat pengetahuan dan sikap ibu dengan variabel dependent yaitu perawatan ISPA pada balita. Untuk menganalisis keeratan hubungan antara dua variabel adalah untuk data kontinu menggunakan uji chisquare.

Tehnik pengambilan sampel secara acak sederhana (simple random sampling), yaitu bahwa setiap anggota atau unit dari 105 populasi mempunyai kesempatan yang sama untuk diseleksi sebagai sampel dengan menggunakan kriteria inklusi yaitu ibu yang mempunyai balita, anak yang didiagnosis ISPA oleh dokter puskesmas kembang seri, ibu yang tinggal di sekitar wilayah kerja Puskesmas Kembang Seri, ibu yang bersedia menjadi responden. Sehingga total sampel dalam penelitian ini berjumlah 51 orang.

Teknik pengumpulan data dengan menggunakan data primer dan sekunder. Data primer yang diperoleh secara langsung dari responden dengan menyebarkan kuesioner yang telah dimodifikasi dari peneliti terdahulu terkait perawatan ISPA oleh ibu yang memiliki balita yang menderita ISPA. Sedangkan data sekunder adalah data yang didapat tidak langsung diberikan ke pengumpul data yang didapatkan peneliti dari dokumen rekam medik puskesmas. Pengumpulan data sekunder di lakukan dengan cara pengambilan data dari puskesmas dan Dinas Kesehatan. Lokasi penelitian di Puskesmas Kembang Seri Kecamatan Talang Empat Kabupaten Bengkulu Tengah waktu penelitian di lakukan pada bulan Agustus-Oktober 2018.

\section{HASIL PENELITIAN Analisis Univariat}

Tabel. 1

Distribusi Frekuensi Pengetahuan Ibu pada Balita yang Menderita Infeksi Saluran Pernapasan Akut (ISPA)

\begin{tabular}{llcc}
\hline No & Variabel pengetahuan & Frekuensi (f) & Presentase (\%) \\
\hline 1 & Kurang & 21 & $41,2 \%$ \\
2 & Cukup & 18 & $35,3 \%$ \\
3 & Baik & 12 & $23,5 \%$ \\
\hline Total & 51 & $100 \%$ \\
\hline
\end{tabular}

Berdasarkan tabel 1 menunjukkan bahwa dari 51 orang mayoritas responden memiliki tingkat pengetahuan kurang yaitu sebanyak 21 orang $(41,2 \%)$.

Tabel. 2

Distribusi Frekuensi Sikap Ibu pada balita yang Menderita Infeksi Saluran Pernapasan Akut (ISPA)

\begin{tabular}{llcc}
\hline No & Variabel Sikap & Frekuensi (f) & Presentase $(\%)$ \\
\hline 1 & Kurang Baik & 27 & $52,9 \%$ \\
2 & Baik & 24 & $47,1 \%$ \\
\hline Total & & 51 & $100 \%$ \\
\hline
\end{tabular}

Berdasarkan tabel 1 menunjukkan bahwa dari 51 orang mayoritas responden memiliki sikap kurang baik yaitu sebanyak 27 orang $(52,9 \%)$. 
Tabel. 3

Distribusi Frekuensi ISPA pada Balita yang Menderita Infeksi Saluran Pernapasan Akut (ISPA)

\begin{tabular}{llcc}
\hline No & Variabel Perawatan & Frekuensi (f) & Persentase $(\%)$ \\
\hline 1 & ISPA & 32 & $62,7 \%$ \\
2 & Tidak ISPA & 19 & $37,3 \%$ \\
\hline Total & 51 & $100 \%$ \\
\hline
\end{tabular}

Berdasarkan tabel 1 menunjukkan bahwa dari 51 orang mayoritas responden memiliki perawatan ISPA yaitu sebanyak 32 orang $(62,7 \%)$.

\section{Analisis Bivariat}

Tabel. 4

Tabulasi Silang antara Pengetahuan Ibu dengan Perawatan Balita yang Menderita Infeksi Saluran Pernapasan Akut (ISPA)

\begin{tabular}{ccccccccr}
\hline \multicolumn{8}{c}{ Perawatan } & \multicolumn{2}{c}{ Total } & P Value \\
\hline Pengetahuan & ISPA & \multicolumn{2}{c}{ Tidak ISPA } & \multicolumn{1}{c}{. } \\
\hline Kurang & $\mathrm{n}$ & $\%$ & $\mathrm{n}$ & $\%$ & $\mathrm{n}$ & $\%$ & \\
\hline Cukup & 18 & 85,7 & 3 & 14,3 & 21 & 100 & \\
Baik & 12 & 66,7 & 6 & 33,3 & 18 & 100 & 0,000 \\
\hline Total & 2 & 16,7 & 10 & 83,3 & 12 & 100 & \\
\hline
\end{tabular}

Berdasarkan tabel 4 menunjukkan tabulasi silang antara pengetahuan ibu dengan terjadinya ISPA, dari 21 orang yang berpengetahuan kurang terdapat 18 orang $(85,7 \%)$ yang mengalami ISPA, dari 18 orang yang berpengetahuan cukup terdapat 12 orang $(66,7 \%)$ yang mengalami ISPA, sedangkan 12 orang yang berpengetahuan baik terdapat 2 orang $(16,7 \%)$ yang mengalami ISPA dan 10 orang $(83,3 \%)$ tidak mengalami ISPA. Hasil anlisis uji pearson chi-square diperoleh nilai $p=0,000 \leq \bar{\alpha} 0,05$, berarti signifikan artinya terdapat hubungan antara pengetahuan ibu dengan perawatan ISPA.

Tabel. 5

Tabulasi Silang antara Sikap Ibu dengan Perawatan Balita yang Menderita Infeksi Saluran Pernapasan Akut (ISPA)

\begin{tabular}{llccccccc}
\hline \multirow{2}{*}{ Sikap } & \multicolumn{5}{c}{ Perawatan } & \multicolumn{2}{c}{ Total } & \multirow{2}{*}{ P Value } \\
\cline { 2 - 7 } & ISPA & \multicolumn{4}{c}{ Tidak ISPA } & & \\
\cline { 2 - 7 } Kurang Baik & 23 & 85,2 & 4 & 14,8 & 27 & 100 & 0,001 \\
Baik & 9 & 37,5 & 15 & 62,5 & 24 & 100 & \\
\hline Total & 32 & 62,7 & 19 & 37,3 & 51 & 100 & \\
\hline
\end{tabular}

Berdasarkan tabel 5 menunjukkan tabulasi silang antara sikap ibu dengan ISPA. Dari 27 orang yang mempunyai sikap yang tidak baik terdapat 23 orang $(82,5 \%)$ yang mengalami ISPA, sedangkan dari 24 orang yang mempunyai sikap baik terdapat 9 orang (37,5\%) yang mengalami ISPA. Hasil analisis uji Pearson chi-square diperoleh nilai $\mathrm{p}$ $=0,000<0,05$, berarti signifikan artinya ada hubungan yang signifikan antara sikap ibu dengan perawatan ISPA. 


\section{PEMBAHASAN}

\section{Hubungan Pengetahuan Ibu dengan Perawatan ISPA}

Dari hasil distribusi frekuensi dengan menggunakan analisis statistik univariat, berdasarkan tingkat pengetahuan dari 51 responden, sebagian besar $(41,2 \%)$ responden pengetahuannya kurang, dan sebagian kecil ibu $(23,5 \%)$ yang berpengetahuan baik.

Berdasarkan hasil analisis statistik menunjukkan bahwa terdapat 12 ibu yang pengetahuan baik dan 2 balita (16,7\%) yang mengalami ISPA. Hal ini karena ketika anak ke lingkungan luar menghirup udara kotor/debu sehingga daya imun tubuhnya menurun, dan 10 responden $(83,3 \%)$ yang tidak mengalami ISPA karena ibu balita memiliki pendidikan yang tinggi, rerata lulusan strata 1 dan memiliki pekerjaan yang dengan pendapatan lebih, dan memperoleh informasi yang cukup tentang penyakit ISPA melalui media massa, tv, surat kabar, internet, dan dari penyuluhan.

Sedangkan yang berpengetahuan cukup terdapat 12 responden $(66,7 \%)$ yang mengalami ISPA. Hal ini karena ibu yang menganggap bahwa batuk dan pilek pada anak balita adalah hal yang normal jadi tidak perlu pengobatan yang serius dan sering tertular dari teman- teman di lingkungannya, dan 6 responden $(33,3 \%)$ yang tidak mengalami ISPA karena ibu cepat mengobati jika ada tanda - tanda balitanya batuk dan pilek sehingga tidak terjadi ISPA. Sedangkan yang berpengetahuan kurang terdapat 18 responden $(85,7 \%)$ yang mengalami ISPA. Hal ini karena responden memiliki tingkat pendidikan yang rendah, dan kurangnya informasi tentang cara perawatan penyakit ISPA pada balita. Sebagian ada 3 responden (14,3\%) yang tidak mengalami ISPA karena ibu yang melakukan hidup bersih sehat (PHBS). Hasil uji statistik diperoleh $\mathrm{p}$ Value $0,000 \leq \bar{\alpha} 0,05$, berarti signifikan artinya ada hubungan pengetahuan ibu dengan perawatan infeksi saluran pernapasan akut (ISPA) pada balita diwilayah kerja Puskesmas Kembang Seri Kecamatan Talang Empat Kabupaten Bengkulu Tengah.

Jalaluddin (2011) mendefinisikan pengetahuan sebagai keseluruhan pemikiran, ide, gagasan, konsep dan pemahaman yang dimiliki manusia tentang dunia dan segala isinya, termasuk manusia dan kehidupannya. Pengetahuan mencakup penalaran, penjelasan dan pemahaman manusia tentang segala sesuatu, juga mencakup praktek atau kemampuan teknis dalam memecah berbagai persoalan hidup yang belum dilakukan secara sistematis dan metodis. Sejalan dengan penelitian Indriani \& Endang (2012) menunjukkan bahwa $37,5 \%$ responden memiliki pengetahuan tentang ISPA dalam kategori sedang. Hal ini mencerminkan bahwa belum semua masalah kesehatan tentang ISPA dapat dipahami oleh responden. Pengetahuan ibu tentang masalah kesehatan pada anak selalu dikaitkan dengan latar belakang pendidikan, pekerjaan, fasilitas pelayanan kesehatan, kunjungan ke pusat pelayanan kesehatan dan kesadaran orang tua tentang pentingnya menjaga kesehatan keluarganya, akan tetapi responden juga dapat menerima pengetahuan dari berbagi sumber, salah satu informasi pendidikan tentang ISPA diperoleh dari petugas kesehatan dan kader posyandu pada saat pelaksanaan kegiatan posyandu.

Peningkatan pengetahuan ISPA responden dapat diperoleh dari berbagai sumber seperti, kegiatan posyandu yang diikuti oleh responden dianjurkan ibu untuk aktif mengikuti kegiatan kader hal ini merupakan salah satu sarana untuk dapat meningkatkan pengetahuan. Sebagian besar responden banyak yang mengunjungi kegiatan posyandu dikarenakan jarak rumah responden dengan posyandu dekat dan sebagian besar responden bekerja sebagai ibu rumah tangga sehingga mempunyai banyak waktu dirumah. Dengan responden mengikuti kegiatan posyandu maka responden bisa mendapat pengetahuan tentang ISPA yang diberikan oleh kader 
posyandu melalui kegiatan penyuluhan kesehatan.

Penelitian Wahyuti (2017) menunjukkan bahwa responden dengan pendidikan SMA, usia ibu 19-29 tahun, dan pekerjaan swasta ini masih banyak pengetahuannya yang kurang tentang ISPA. Sedangkan dari hasil penelitian Indriani (2018) menunjukkan bahwa pendidikan SD, umur 21-28 tahun, dan pekerjaan ibu rumah tangga yang masih banyak pengetahuannya kurang tentang ISPA. Hasil penelitian Safrizal tahun (2017) menyatakan Perawatan anak dengan ISPA sangat berkolaborasi dengan kondisi ventilasi yang kurang, lantai yang kotor, dinding yang berdebu, dan atap rumah yang banyak sarang laba-laba sehingga mempengaruhi Kejadian ISPA tersebut.

\section{Hubungan Sikap Ibu dengan Perawatan ISPA}

Dari hasil analisis statistik deskriptif statistik frekuensi dari 51 responden, sebagian $(52,9 \%)$ responden kurang baik dan yang bersikap baik $(47,1 \%)$ responden. Berdasarkan analisis statistik didapatkan bahwa dari 24 orang ibu yang mempunyai sikap yang baik terdapat 9 orang $(37,5 \%)$ yang mengalami ISPA. Hal ini karena menurut orang tua anak mereka alergi dingin karena perpindahan dari musim panas ke musim hujan, dan 15 orang $(62,5 \%)$ yang tidak mengalami ISPA karena orang tua sering memberi makanan yang bergizi, dan lingkungan rumah yang selalu dijaga kebersihannya. Sedangkan 29 dari responden yang mempunyai sikap tidak baik terdapat 23 orang $(85,2 \%)$ yang mengalami ISPA. Hal ini karena kurang pemberian asupan gizi yang baik, lingkungan rumah yang kurang bersih dan pendidikan yang rendah. Sedangkan sebagian 4 orang $(14,8 \%)$ yang tidak mengalami ISPA karena orang tua mengetahui cara pencegahan penyakit ISPA seperti selalu menganjurkan anak untuk cuci tangan sebelum dan setelah makan, konsumsi sayuran dan lingkungan rumah bersih.

Hasil uji statistik diperoleh p-value $(0,000)<0,05$, berarti signifikan artinya ada hubungan sikap ibu dengan perawatan infeksi saluran pernapasan akut (ISPA) pada balita di wilayah kerja puskesmas kembang seri kecamatan talang empat Kabupaten Bengkulu tengah.

Sikap merupakan kesiapan atau kesedihan untuk bertindak dan bukan merupakan pelaksanaan motif tertentu. Dalam kata lain fungsi sikap belum merupakan predisposisi perilaku (tindakan) atau reaksi tertutup. Sikap merupakan reaksi atau respon yang masih tetap dari seseorang terhadap sesuatu stimulus atau objek, sikap belum merupakan tindakan atau perilaku/peran. Sikap masih merupakan reaksi tertutup, bukan merupakan reaksi terbuka, merupakan reaksi terhadap obyek dilingkungan tertentu sebagai suatu penghayatan terhadap obyek (Notoadmodjo, 2010).

Keluarga merupakan bagian dari tim pengobatan dan perawatan. Para anggota keluarga menunggui secara bergantian, bahkan sering menjaga bersama-sama. Sementara perawat di rumah sakit yang seharusnya merawat orang sakit juga harus melakukan tugas-tugas yang lain di bangsal perawatan. Maka, peran keluarga penting untuk memantau kebutuhan pasien dari laporan perawat atau jika perlu malakukan komunikasi langsung. Peranan tersebut lebih dominan dari seorang ibu. Beberapa peranan ibu dalam melakukan upaya perawatan ISPA pada anakanya yaitu ibu harus mengetahui tentang ISPA mulai dari pengertian, penyebab, tanda dan gejala, proses perjalanan penyakit, komplikasi dan cara mengobati dan merawat anak semasa sakitnya tersebut agar bisa melakukan perawatan sedini mungkin dan sudah tahu bagaimana cara pencegahan ISPA tersebut (Choirunisa, 2015). 
Ibu yang bersikap baik akan menyikapi kondisi balitanya saat menderita ISPA dengan perawatan yang baik, sehingga ibu akan bersikap peduli terhadap balitanya, dengan bersikap bagaimana cara mencegah ISPA. Ibu yang bertanggung jawab akan mendukung itu semua, hal ini juga disebutkan oleh WHO (2018) bahwa ISPA banyak menyerang balita, terutama anak yang kurang perhatian dari ibunya.

Perjalanan klinis penyakit ISPA pada balita dimulai dengan berinteraksinya virus dengan tubuh. Masuknya virus sebagai antigen ke saluran pernapasan menyebabkan silia yang terdapat pada permukaan saluran napas bergerak ke atas mendorong virus ke arah faring atau dengan suatu tangkapan refleks spasmus oleh laring. Jika refleks tersebut gagal maka virus merusak lapisan epitel dan lapisan mukosa saluran pernapasan. Iritasi virus pada kedua lapisan tersebut menyebabkan timbulnya batuk kering. Kerusakan struktur lapisan dinding saluran pernapasan menyebabkan kenaikan aktivitas kelenjar mukus yang banyak terdapat pada dinding saluran napas, sehingga terjadi pengeluaran cairan mukosa yang melebihi normal. Rangsangan cairan yang berlebihan tersebut menimbulkan gejala batuk. Sehingga pada tahap awal gejala ISPA yang paling menonjol adalah batuk (Chang, 2009).

Balita sangat tinggi dan beresiko terkena ISPA, hal ini juga di tentukan pada kemampuan ibu dalam memberikan perhatian, perawatan dan pengobatan kepada balitanya, yang diawali dengan sikap yang menunjukkan perilaku kesehatan. Perilaku kesehatan pada dasarnya adalah suatu reaksi seseorang terhadap stimulus atau rangsangan yang berkaitan dengan sakit atau penyakit. Reaksi tersebut bisa pasif (Pengetahuan, dan sikap) maupun aktif (berupa tindakan) (Hartono \& Rahmawati, 2012).

Menurut Syarifudin (2005) bahwa sikap juga dipengaruhi oleh faktor ekstern dan intern, salah satunya adalah pengalaman. Apa yang telah dan sedang kita alami akan ikut membentuk dan mempengaruhi penghayatan kita terhadap stimulus. Hal ini lebih ditegaskan oleh Azwar (2009) yang menyatakan sikap itu merupakan kesiapan untuk bertindak.

\section{SIMPULAN}

Menurut pengamatan peneliti masih kurangnya sikap ibu dalam melakukan perawatan pada balita yang menderita ISPA, dikarenakan kurangnya kesadaran dalam mencari promkes di puskesmas, faktor umur dan menikah terlalu muda, sehingga pengalaman atau pengetahuan ibu kurang dalam perawatan balita yang menderita ISPA.

Ada hubungan yang signifikan antara pengetahuan ibu dengan perawatan ISPA pada balita di wilayah kerja Puskesmas Kembang Seri Kecamatan Talang Empat Kabupaten Bengkulu Tengah tahun 2015. Ada hubungan yang signifikan antara sikap ibu dengan perawatan ISPA pada balita di wilayah kerja Puskesmas Kembang Seri Kecamatan Talang Empat Kabupaten Bengkulu Tengah tahun 2015.

\section{SARAN}

\section{Bagi Institusi Akademik}

Diharapkan bagi instansi akademik mampu melatih calon tenaga kesehatan khususnya mahasiswa jurusan ilmu keperawatan agar menjadi lebih terampil dalam memberikan penyuluhan kesehatan terkait ISPA kepada masyrakat guna menaikkan pengetahuan kesehatan yang lebih baik. 


\section{Bagi Puskesmas Kembang Seri}

Diharapkan sebagai bahan informasi untuk meningkatkan pengetahuan serta kemampuan tenaga kesehatan dalam penatalaksanaannya kejadian infeksi saluaran pernapasan akut (ISPA) di wilayah kerjanya.

\section{Bagi Peneliti Lain}

Diharapkan bagi peneliti lain agar lebih mengembangkan ruang lingkup penelitian ini dengan melihat karakteristik lain seperti : Jarak rumah klien dengan pusat pelayanan kesehatan, pendapatan keluarga, dan keaktifan orang tua dalam mengikuti kegiatan penyuluhan kesehatan di puskesmas.

\section{Orangtua}

Hasil Penelitian ini diharapkan dapat berguna bagi para ibu untuk menambah pengetahuan dan informasi tentang kejadian ISPA pada balita serta meningkatkan kemampuan ibu dalam memberikan perawatan kesehatan kepada balitanya sehingga menggurangi angka kejadian ISPA pada balita.

\section{DAFTAR PUSTAKA}

Azwar, S. (2009). Sikap Manusia Teori dan Pengukurannya. Yogyakarta: Pustaka Pelajar

Chang, C. (2009). Patofisiologi Aplikasi Praktik Keperawatan. Jakarta: EGC

Choirunisa, C. (2015). Panduan Terpenting Merawat Bayi dan Balita. Yogyakarta: Moncer Pubhlisher

Dinkes Bengkulu Tengah. (2017). Profil Kesehatan Kabupaten Bengkulu Tengah Tahun 2016. Dinkes Bengkulu Tengah

Hartono, H., \& Rahmawati, R. (2012). Gangguan Pernafasan pada Anak ISPA. Yogyakarta: Nuha Medika

Indriani, D., \& Endang, Z. (2012). Hubungan Tingkat Pengetahuan Ibu tentang Infeksi Saluran Pernafasan Akut (ISPA) dengan Perilaku Pencegahan pada Balita di Wilayah Kerja Puskesmas Tirto II Kabupaten Pekalongan. https://publikasiilmiah.ums.ac.id/xmlui/handle/11617/3666

Jalaludin, R. (2011). Metode Penelitian Komunikasi. Bandung: Remadja Karya

Kemenkes RI. (2017). Profil Kesehatan Indonesia 2016 dan Informasi Kesehatan smaller size -web.pdf-Diakses dari http://www. Depkes.go.id/ resources / download/ pusdatin/lain-lain/ Data Agustus 2017

Notoatmodjo, S. (2010). Promosi Kesehatan: Teori dan Aplikasinnya. Jakarta

Padila, P. (2012). Buku Ajar Keperawatan Medikal Bedah. Yogyakarta: Nuha Medika

Padila, P. (2013). Buku Ajar Keperawatan Keluarga. Yogyakarta: Nuha Medika

Prabowo, P. (2012). Penyakit yang Paling Umum pada Anak. Jakarta: Majalah Kesehatan. PT Asdi Mahasatya

Riset Kesehatan Dasar. (2018). http://www.libitang.depkes.go.id/sites/download /buku_laporan/lapnas_rikesdas2010/Laporan_rikesda_2010.pdf. diakses tanggal 12 November 2018 Jam. 04.00 WIB

Safrizal, S. A. (2017). Hubungan Ventilasi, Lantai, Dinding, dan Atap dengan Kejadian ISPA pada Balita di Blang Muko. Prosiding Seminar Nasional IKAKESMADA "Peran Tenaga Kesehatan dalam Pelaksanaan SDGs"

Sucipto, C. D. (2011). Vektor Penyakit Tropis. Yogyakarta: Gosyen Publishing 
Syarifudin, S. (2005). Sikap Manusia: Teori dan Pengukurannya. Bandung: Mandar Maju

Wahyuti, I. (2017). Hubungan antara Pengetahuan Orang Tua tentang Ispa dengan Kejadian Ispa pada Bayi di Wilayah Kerja Puskesmas Gatak Sukoharjo. Jurnal Kesehatan. 5(1), 56-65

World Health Organization. (2008). Epidemic-prone \& Pandemic-prone Acute Respiratory Diseases: Infection Prevention \& Control in Health-Care Facilities. Summary Guidance. Jenewa : WHO

World Health Organization. (2018). Pencegahan dan Pengendalian Infeksi Saluran Pernapasan Akut (ISPA) yang Cenderung menjadi Epidemi dan Pandemi di Fasilitas Pelayanan Kesehatan. Geneva. Alih bahasa: Trust indonesia. Diperoleh pada tanggal 2 Mei 2017 http://www. who. int/healthinfo/global_burden_disease/ GBD_report_2018 update_full.pdf 